\title{
Effect of dietary supplementation with Morinda citrifolia on productivity and egg quality of laying hens
}

\section{Efecto de la suplementación dietética con Morinda citrifolia sobre la productividad y la calidad del huevo de gallinas ponedoras}

Fecha de recepción: 14 de febrero de 2015 Fecha de aprobación: 19 de junio de 2015
Dairon Más-Toro' ${ }^{1}$ Yordan Martínez-Aguilar² Román Rodríguez-Bertot ${ }^{3}$, Cesar Betancur-Hurtado ${ }^{4}$

Osmani Rosabal-Nava ${ }^{5}$

\begin{abstract}
In order to evaluate the dietary supplementation of powdered leaves of Morinda citrifolia on productivity and egg quality of laying hens, a total of 160 White Leghorn birds (Hybrid L- ${ }_{33}$ ) of 27 weeks of age were allotted during 70 days, according to completely randomized design. Dietary treatments consisted of a control diet fed without or with $0.5,1.0$ and $1.5 \%$ of powdered leaves of M. citrifolia. Supplementation of 1.0 and $1.5 \%$ of M. citrifolia powder increased the egg weight $(P<0.05)$, however, laying intensity, body weight, feed intake, unsuitable eggs, eggshell surface, mass conversion, haugh units and height of the dense white and of the yolk showed no significant differences ( $P>0.05)$ among treatments. Also, supplementation of 0.5 and $1.0 \%$ of $M$. citrifolia increased the shell thickness and the yolk color was pigmented by this medicinal plant. It recommended the dietary supplementation of $1.0 \%$ of powdered leaves of M. citrifolia on laying hen diets to improve the egg weight, shell thickness and yolk color.
\end{abstract}

Keywords: Egg, laying hen, noni, productivity, quality.

1 Universidad de Granma (Bayamo-Granma, Cuba).

2 Ph.D. Universidad de Granma (Bayamo-Granma, Cuba).ymartineza@udg.co.cu.

3 Ph.D. Universidad de Granma (Bayamo-Granma, Cuba).rrodriguezb@udg.co.cu.

4 M.Sc. Universidad de Córdoba (Córdoba-Montería, Colombia).

5 Universidad de Granma (Bayamo-Granma, Cuba). 


\section{Resumen}

Para evaluar la suplementación de polvo de hojas de Morinda citrifolia sobre la productividad y la calidad de huevos de gallinas ponedoras, un total de 160 aves White Leghorn (híbridas L- ${ }_{33}$ ) de 27 semanas de edad, se ubicaron durante 70 días, según un diseño totalmente aleatorizado. Los tratamientos consistieron en una dieta control sin o con $0.5,1.0$ y $1.5 \%$ de polvo de hojas de $M$. citrifolia. La suplementación de 1.0 y $1.5 \%$ de $M$. citrifolia incrementó el peso del huevo $(\mathrm{P}<0.05)$, sin embargo, la intensidad de puesta, el peso vivo, el consumo de alimento, los huevos no aptos, la superficie de la cáscara, la conversión masal, las unidades haugh y la altura de la clara densa y de la yema no mostraron diferencias significativas $(\mathrm{P}>0.05)$ entre tratamientos. Además, la suplementación de 0.5 y $1.0 \%$ de $\mathrm{M}$. citrifolia incrementó el grosor de la cáscara y el color de la yema se pigmentó por esta planta medicinal. Se recomienda la suplementación de $1.0 \%$ de polvo de hojas de M. citrifolia en las dietas de las gallinas ponedoras para mejorar el peso del huevo, el grosor de la cáscara y el color de la yema.

Palabras clave: Huevo, gallina ponedora, noni, productividad, calidad. 


\section{Introduction}

Natural products are an alternative to the indiscriminate use of antibiotics as growth promoters in farm animals. For its beneficial properties the prebiotics, probiotics and plant extracts have been used as supplements in diets of birds, with the objective to improve health status, reduce pathogens, modulate immune response and increase the productive indicators (1). Plant additives are considered to be technically, biologically and economically viable alternatives to replace chemical antibiotics, as they present fewer safety concerns, related to inclusion levels and residuals in the end product (2).

Morinda citrifolia (noni), wich originated in India, but is now spread around the world, belongs to the family Rubiaceae, is reported to have many medicinal properties, including antibacterial, antiviral, antifungal, antitumor, anthelmintic, analgesic, anti-inflammatory, hypotensive and immunostimulant activities $(3,4)$. However, the potential for powdered leaves of $M$. citrifolia to be used as a supplement in poultry diets, has not been yet evaluated. Therefore, this is the objective of the current study to evaluate the effect of dietary supplementation with Morinda citrifolia on productivity and egg quality of laying hens performance.

\section{Materials and methods}

Leaves of $M$. citrifolia obtained from trees that were approximately two years old and grown in the area of Peralejo, Granma, Cuba. Leaves that were relatively uniform in size and structure were collected, dried at $60^{\circ} \mathrm{C}$ for 12 hours and ground to pass through a $1 \mathrm{~mm}$ screen. Ground samples were stored at room temperature in airtight plastic bags.

A total of 160 White Leghorn laying hens (Hybrid $\mathrm{L}_{33}$ ) of 27 weeks old were allotted during 70 days, according a completely randomized design with four treatments, 10 replicates per treatment and four birds per replicate. Dietary treatments consisted of a control diet fed without (T0) or with
0.5 (T1), 1.0 (T2) and 1.5\% (T3) supplemental $M$. citrifolia powder.

Diet based on corn and soybean meal was formulated, according to the nutritional requirements for laying hens proposed by UECAN (5). The experimental unit was a $40 \times 40 \mathrm{~cm}$ metallic cage, where four hens were assigned. Birds received $110 \mathrm{~g}$ of feed/hen/day. The water was supplied ad libitum, through two-nipple drinkers/cage, and, every day, 16 hours of light were provided.

The initial and final weight of the laying hens was individually performed, at 27 and 37 weeks of age, through a digital SARTORIUS (model BL 1500). Egg weight was taken weekly to 20 eggs/treatment, and average weight was estimated. Feed intake and $M$. citrifolia consumption were determined daily by the offer and rejection method.

In order to determine the laying intensity, the total egg production/week/treatment was considered and it was assumed as $100 \%$ one egg/day/bird allocated. Mass conversion was calculated through feed intake, egg weight per replication and number of eggs laid. At the end of the experiment, the viability and eggs unsuitable were also calculated.

At 37 weeks of the experiment, eggs (20) were also collected to measure shell thickness (median, superior and inferior pole) with a micrometer screw ( $\pm 0.01 \mathrm{~mm}$ precision), and calculated shell surface with the formula: area $=3.9782 \mathrm{~W}^{0.7056}$, where $\mathrm{W}=$ egg weight (g). Albumin and yolk height were measured with a height calibrator (FHK; $\pm 0.01 \mathrm{~mm}$ precision). The Haugh units were calculated with the formula $\mathrm{HU}=100 \log \left[\mathrm{H}+7.57-1.7 \mathrm{~W}^{0.37}\right]$; where $\mathrm{HU}=$ Haugh units, $\mathrm{H}=$ albumin height and $\mathrm{W}=$ egg weight. The yolk color was determined by Roche's range of 15 colors.

Data were processed by analysis of variance (Anova) of simple classification, in completely randomized design. In the necessary cases Duncan's test was applied to determine mean differences. The percentage of eggs unsuitable was analyzed by comparison of proportion. All the data 
from the statistical analysis were processed with the SPSS software, version 17.0.

\section{Results and discussion}

Table I shows that the viability indicates no significant differences $(P>0.05)$ among treatments, demonstrating the safety of the product used for 70 days. In this sense, Aguilar et al. (6) have reported the effectiveness of natural products in feed for non-ruminant animals, because of its low residual and its regulator effect on organic functions.

Table I. Effect of dietary supplementation with Morinda citrifolia on productivity and egg quality of laying hens ( 27 to 37 weeks).

\begin{tabular}{|c|c|c|c|c|c|c|}
\hline \multirow[t]{2}{*}{ Items } & \multicolumn{4}{|c|}{$\begin{array}{l}\text { Supplementation of } M \text {. citrifolia powder } \\
\qquad(\%)\end{array}$} & \multirow[b]{2}{*}{ SEM \pm} & \multirow[b]{2}{*}{$P$-value } \\
\hline & Control & 0.5 & 1.0 & 1.5 & & \\
\hline Viability (\%) & 100 & 100 & 100 & 100 & & \\
\hline Laying intensity (\%) & 80.18 & 82.61 & 80.86 & 79.43 & 1.06 & 0.181 \\
\hline Feed intake (g/bird/d) & 110 & 110 & 110 & 110 & & \\
\hline M. citrifolia intake (g/bird/d) & 0.00 & 0.55 & 1.1 & 1.65 & & \\
\hline Mass conversion (kg/kg) & 2.61 & 2.51 & 2.55 & 2.57 & 0.07 & 0.28 \\
\hline Egg weight (g) & $53.08^{\mathrm{b}}$ & $53.77^{\mathrm{ab}}$ & $54.18^{\mathrm{a}}$ & $54.55^{\mathrm{a}}$ & 0.28 & 0.002 \\
\hline Initial body weight (g) & 1667 & 1660 & 1645 & 1655 & 39.92 & 0.98 \\
\hline Final body weight (g) & 1679 & 1696 & 1672 & 1668 & 27.82 & 0.17 \\
\hline Cracked eggs (\%) & 0.22 & 0.13 & 0.18 & 0.13 & 0.09 & 0.28 \\
\hline Broken eggs (\%) & 0.00 & 0.04 & 0 & 0.04 & 0.03 & 0.65 \\
\hline Eggs without a shell (\%) & 0.04 & 0.00 & 0.04 & 0.09 & 0.03 & 0.71 \\
\hline Index form (\%) & 73.75 & 76.88 & 78.37 & 76.28 & 2.04 & 0.29 \\
\hline Eggshell thickness (mm) & $0.27^{c}$ & $0.37^{\mathrm{a}}$ & $0.36^{\mathrm{a}}$ & $0.34^{\mathrm{b}}$ & 0.01 & $\leq 0.001$ \\
\hline Eggshell surface $\left(\mathrm{cm}^{2}\right)$ & 44.89 & 46.15 & 45.11 & 45.92 & 0.81 & 0.65 \\
\hline Height of the dense white (mm) & 6.31 & 6.21 & 6.45 & 6.11 & 0.13 & 0.33 \\
\hline Yolk height (mm) & 7.19 & 7.21 & 7.21 & 7.20 & 0.22 & 0.52 \\
\hline Haugh units & 80.47 & 78.98 & 81.24 & 78.44 & 1.03 & 0.24 \\
\hline Yolk color & $6.25^{\mathrm{b}}$ & $6.75^{\mathrm{a}}$ & $6.65^{\mathrm{a}}$ & $6.70^{\mathrm{a}}$ & 0.13 & 0.03 \\
\hline
\end{tabular}

a,b,c Means with different superscript letters within a row differ $(P<0.05)$.

Likewise, feed intake, body weight, laying intensity, mass conversion and the percentage of eggs unsuitable did not show significant differences among treatments $(P>0.05)$, despite a higher consumption of $M$. citrifolia (Table I). These results agree with Martínez et al. (7), who found that the supplementation of $A$. occidentale did not decrease these indicators. This could indicate that the secondary metabolites added on experimental diets did not cause symptoms related to anti-nutritional factors, according to Savón et al. (8), an excess of these, could decrease the body weight and production indicators.

However, supplementation of 1.0 and $1.5 \%$ of $M$. citrifolia increased the egg weight compared to the other treatments $(\mathrm{P}<0.05)$ (Table I). According to Brito et al. (4) the alkaloids detected in the 
leaves of $M$. citrifolia have beneficial effects in small quantities and are potent bactericidal against strains of Staphylococcus aureus and Escherichia coli, which could increase the intestinal health and nutrient digestibilities (mainly minerals) (6), and hence egg weight. Similar results were found by Ghasemi et al. (2) when they used Allium sativum and Thymus vulgaris.

Moreover, index form, Haugh units and height of the dense white and of the yolk did not indicate significant differences among treatments $(P>0.05)$. Usually the medicinal effects of plants are for its content in secondary metabolites; however, its effect depends of the concentration of these compounds and its supplementation in the diets $(6,7)$.

However, supplementation of 0.5 and $1.0 \%$ of $M$. citrifolia increased the shell thickness compared to the control and supplementation of $1.5 \%$ of $\mathrm{M}$. Citrifolia $(\mathrm{P}<0.05)$. Also, the yolk color was pigmented with this medicinal plant (Table I).

In this sense, by the antibacterial properties of the leaves of $M$. citrifolia $(3,4)$ its supplementation on laying diets (especially with supplementation of $1.0 \%$ ), could improve the intestinal health (4), through an increase in competitive exclusion and a decrease of the intestinal $\mathrm{pH}$, which influence in the digestion and absorption of calcium, and in turn, on the thickness of the shell (6), taking into account that are required suitable conditions of $\mathrm{pH}$ by the insolubility or instability of this mineral (8). For these characteristics and taking into account the $M$. citrifolia intake (Table I) can affirm a direct effect of secondary metabolites of $M$. citrifolia powder, because the animals, especially the birds cannot synthesize them.

In the yolk color (Table I) could have influenced the anthocyanins, secondary metabolite abundant in the leaves of $M$. citrifolia, which is regarded a natural colorant on the upper floors (9). According to Martínez et al. (7), this metabolite can influence on the yolk pigmentation; however, these authors have reported an increase of the yolk color to a higher supplementation of $A$. occidentale in the diets of laying hens (8 to 10). This shows that the pigmentation of the yolk may be determined by the amount of pigments in the diet, intensity, absorption and deposition in the yolk.

\section{Conclusions}

Supplementation of $1.0 \%$ of M. citrifolia powder is recommended on laying hen diets to improve the egg weight, shell thickness and yolk color.

\section{Acknowledgement}

We are grateful with the executive staff and technicians of the laying hen farm "Antonio Maceo" for their collaboration in the development of this investigation.

\section{References}

(1) Kong X. F., Y. L. Hu, and R. Rui (2004). Effects of Chinese herbal medicinal ingredients on peripheral lymphocyte proliferation and serum antibody titer after vaccination in chicken. Int. Immunopharmacol. 4(7): 975-982. DOI: http:// dx.doi.org/10.1016/j.intimp.2004.03.008.

(2) Ghasemi R., M. Zarei, and M. Torki (2010). Adding medicinal herbs including garlic (Allium sativum) and thyme (Thymus vulgaris) to diet of laying hens and evaluating productive performance and egg quality characteristics. American J. Animal Vet. Sci. 2(2): 151-154. DOI: http://dx.doi.org/10.3844/ajavsp.2010.151.154.

(3) Wang M. Y., B. J. West, C. J. Jensen, D. Nowicki, C. Su, A. K. Palu, and G. Anderson (2002). Morinda citrifolia (Noni): a literature review and recent advances in Noni research. Acta Pharmacol. Sin. 23: 1127-1141.

(4) Brito D. R., R. M. Fernandes, M. Z. Fernandes, M. D. Ferreira, F. R. Rolim, and M. L. Filho (2009). Anthelmintic activity of aqueous and ethanolic extracts of Morinda citrifolia fruit on Ascaridia galli. Rev. Bras. Parasitol. Vet. 18(4): 32-36. DOI: http://dx.doi.org/10.4322/ rbpv.01804006. 
(5) Unión Estatal del Centro Avícola Nacional (UECAN) (2011). Manual tecnológico para la cría de aves. Ponedoras y sus reemplazos. 5nd Ed Ministerio de la Agricultura (Havana). 9 p.

(6) Aguilar Y., O. Martínez, G. Liu, W. Ren, R. Bertot, Y. Jiménez, C. González, M. del Toro, A. Ginarte, M. Navarro, and C. M. Nyachoti (2013). Effect of dietary supplementation with Anacardium occidentale on growth performance and immune and visceral organ weights in replacement laying pullets. J. Food Agric. Environ. 13(3\&4): 1352-1357.

(7) Martínez Y., A. Escalona, O. Martínez, C. Olmo, R. Rodríguez, M. Iser, C. Betancur, M. Valdivié, and G. Liu (2012). The use of Ana- cardium occidentale as nutraceutical in hypoprotein diets for laying hens. Cuban J. Agricult. Sci. 46(4): 395-401.

(8) Savón L., I. Scull, and M. Martínez (2007). Integral foliage meal for poultry feeding. Chemical composition, physical properties and phytochemical screening. Cuban J. Agricult. Sci. 41(2): 359-361.

(9) Pazmi-o-Duran E. A., M. M. Giusti, R. E. Wrolstad, and M. B. Gloria (2001). Anthocyanins from banana bracts (Musa paradisiaca) as potential food colorants. Food Chem. 73(3): 327-332. DOI: http://dx.doi.org/10.1016/ S0308-8146(00)00305-8. 